\title{
Renewable Energy Operation and \\ A Summary of Discussions During the Seminar on Conversion Schemes Energy Systems
}

GIOVANNI SPAGNUOLO, GIOVANNI PETRONE, SAMUEL VASCONCELOS ARAÚJO, CARLO CECATI, ERIK FRIIS-MADSEN, EUGENIO GUBÍA, DANIEL HISSEL, MAREK JASINSKI, WILFRIED KNAPP, MARCO LISERRE, PEDRO RODRIGUEZ, REMUS TEODORESCU, and PETER ZACHARIAS

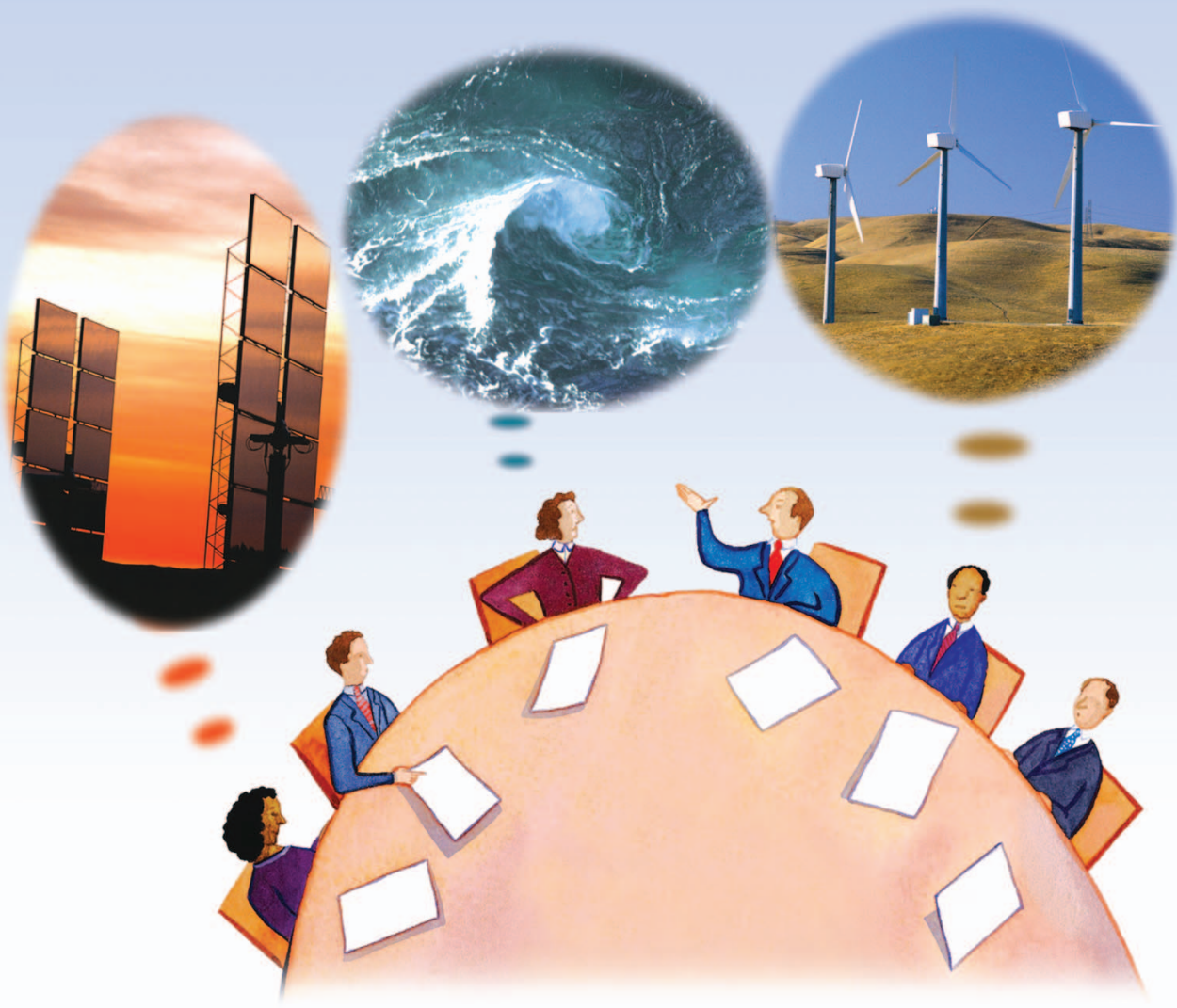

(๑) STOCKBYTE, DIGITAL VISION \& PHOTODISC

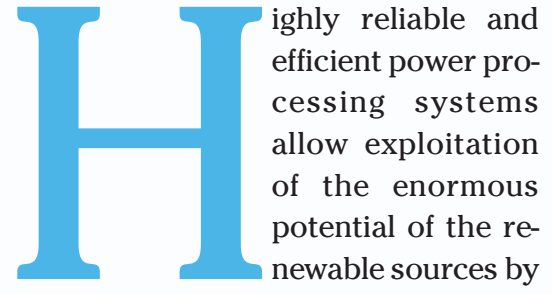

transforming the maximum available power into an electrical one, fed into the grid or converted into a highdensity energy vector for being stored and used in another place or at another time, when the primary source is not available.

Such topics were discussed at the Seminar on Renewable Energy system (SERENE) held 12-13 June 2009 in Salerno, Italy. The seminar was sponsored by the University of Salerno and the IEEE Industrial Electronics Society (IES) through the Technical Committee on Renewable Energy Systems and Educational Committee.

This article is an attempt at summarizing the most important contributions of SERENE. It is organized as follows: first, the most promising future source of energy, i.e., photovoltaics (PVs), is treated with respect to the maximization of energy extraction, the maximization of efficiency, and reliability with silicon carbide (SiC) devices and power converter structures; then, one of the most challenging energy sources, wave energy, is discussed with reference to the results of the Wave Dragon European project; finally, integration of these sources into the power grid through smart-grid technologies based on the 
grid converter and the use of hydrogen as the main energy vector for stationary power plants are illustrated.

\section{PV Systems}

The use of energy coming from the Sun and hitting Earth has been dramatically increasing in the last few years. Apart from the solar thermal plants, the spreading of PV systems is being encouraged by the feed-in tariffs and by the drop in crystalline cells' prices. The latter factor in 2009 has boosted the sales of large PV power plants as well as domestic installations, with a growing trend in 2010 , because the pay-back plan benefits of tariffs for the produced energy still remains high with respect to the forecast for future years.

In this scenario, the market has increased the need for power processing systems characterized by high efficiency and low cost, both for lowpower (e.g., few kilowatts) and highpower applications. The former figure can be improved by working on conversion efficiency and maximum power point tracking (MPPT) efficiency, whose product results in the total efficiency of the power processing system: $\mathrm{SiC}$ devices give a significant contribution in maximizing the electrical conversion efficiency, and an in-depth analysis of the disturbances appearing in grid-connected systems helps in improving the MPPT efficiency. The goal of exploiting several distributed power sources with lowvoltage levels or to process high power with lower current can be achieved with multilevel architectures.

As for the cost aspect, current literature indicates that the future of PV-dedicated conversion systems is in the adoption of transformerless topologies, with additional benefits in terms of conversion efficiency. Such aspects have been detailed in the sections that follow.

\section{MPPT Issues}

The MPPT is one of the key functions in any PV system, because it ensures that the maximum available electrical power is produced by the PV array at any irradiance and temperature values. As evident from the example reported in Figure 1, the locus of the maximum power points is a large area in the power versus voltage plane.

MPPT performances in steadystate weather conditions as well as during transients in the irradiance level can be heavily penalizing for the total efficiency of the entire PV power processing system, because it is given by the product of MPPT efficiency and electrical efficiency of the conversion chain.

The two most frequently used MPPT algorithms are perturb and observe (P\&O) [1] and incremental conductance (IC). Both of them are based on a repeated adjustment of the PV voltage to detect the fulfillment of a proper condition involving the actual values of the PV current, voltage, and power. They are usually implemented in the way described in Figure 2, where it is shown by the PV array, a dc/dc boost converter, the load or another switching converter (e.g., a dc/ac stage) by means of a resistor, and the MPPT block using the measures of PV current and voltage to drive the controlled switch appropriately. The PV field has been described by using its single-diode model [2], the boost converter, usually needed for stepping the PV field voltage up to the level needed by the load or by an inverting stage connected to the ac mains, matches the load to the PV generator so that the latter produces the maximum possible power. The MPPT controller straight forwardly adjusts the duty cycle or does the same by varying the reference voltage in an usual pulsewidth modulation (PWM) to ensure that the PV array works at a voltage

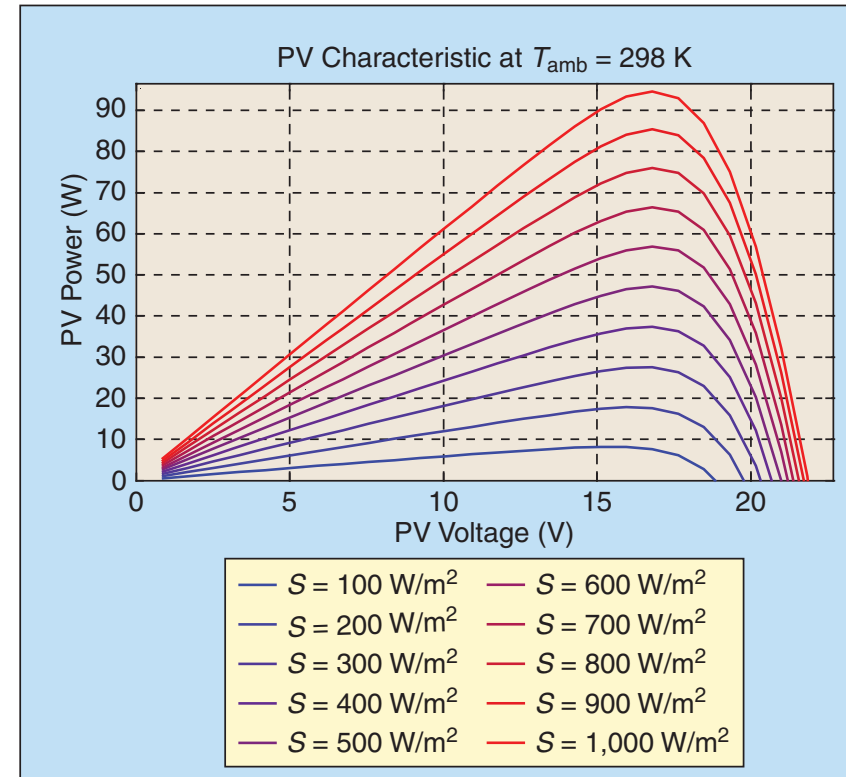

(a)

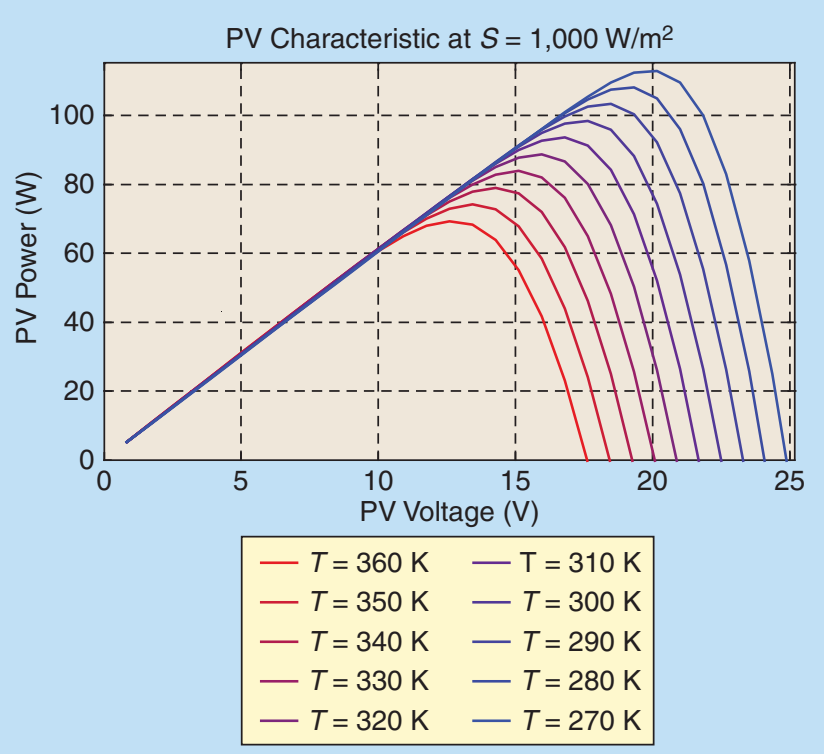

(b)

FIGURE 1 - The PV characteristics of a Kyocera KC120 module with varying temperature and irradiance. 


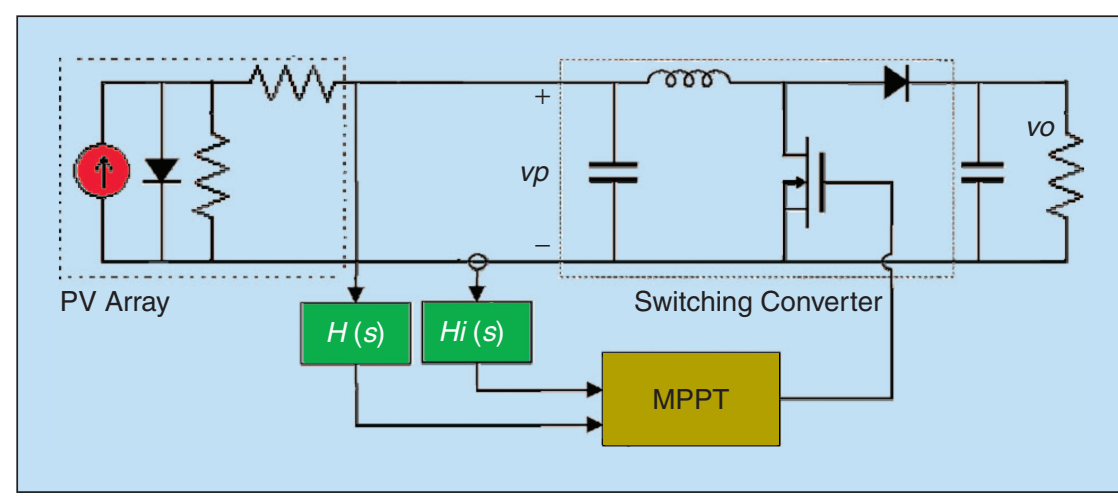

FIGURE 2-A typical implementation of an MPPT technique.

level resulting in the maximum produced power.

With the same principle, the MPPT technique can be applied to singlestage power processing topologies that do not include the dc/dc converter but employ a dc/ac stage only.

Both P\&O and IC MPPT algorithms change the dc/dc converter duty cycle to detect the change of the sign or the null of the derivative of the PV power with respect to the PV voltage [3]. The MPPT efficiency is influenced by a poor parametric design of the algorithm and by the deceiving effect of disturbances originating in the dc/ac stage of the power processing system and propagating backward to the PV array.

As for the first aspect, the amplitude and frequency of the PV voltage perturbations must be designed according to the desired performances at a constant and with a time-varying irradiance. If a too high frequency is settled, the controller might be deceived by the effects of the system's dynamics, but a too low value slows down the MPPT algorithm response to fast irradiance variations. On the other hand, a small amplitude of the perturbations ensures high performances in steady state but worsens them during fast irradiance transients.

A recipe for the optimal design of the MPPT algorithm has been presented in [3], and further measures have been discussed for making the algorithm reliable in single-phase ac applications too. In this case, the performances of any MPPT algorithm, although optimally designed, are deteriorated by a voltage oscillation arising at the dc bus and backpropagating to the PV array. This induces a periodic perturbation of the PV fieldoperating voltage at twice the ac frequency with a worsened MPPT efficiency. The reason of this phenomenon is explained in Figure 3, where the role of the bulk capacitor in terms of balancing the dc power produced by the PV array and the alternating (at twice the grid frequency) ac power requested by the load or injected into the grid is put into evidence.

Some solutions to this drawback, avoiding any passive filtering and thus preserving the efficiency of the conversion chain, have been presented in

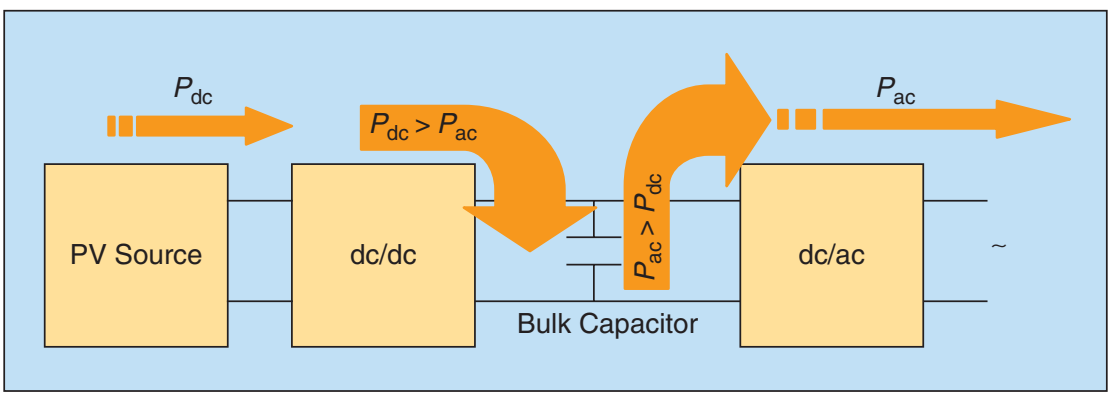

FIGURE 3-Power fluxes in a two-stage inverter and the source of oscillations at twice the ac frequency.

the literature. Some solutions are based on a suitable modulation of the $\mathrm{dc} / \mathrm{dc}$ converter duty cycle to allow the requested oscillation of the bulk voltage and, at the same time, to keep the PV field voltage immune from this disturbance.

The increased interest in novel architectures based on the adoption of switching converters employing a PV module-dedicated decentralized MPPT function is giving rise to new challenging problems. The distributed-MPPT (DMPPT) philosophy, which is also stimulating some industries to the production of DMPPT dedicated devices, allows for reducing the impact of the mismatching effect [4], but its implementation requires further studies in terms of interactions among different systems, employing the MPPT function at the same time.

\section{SiC Devices in PV Power Processing Systems}

$\mathrm{SiC}$ semiconductors have a high potential for enhancements of the electrical conversion efficiency of PV systems. In addition, high switching frequencies inherent to such devices will also enable decrease of weight and cost. Nevertheless, other outstanding characteristics of such components will also play an important role in future developments of other system characteristics such as reliability, maintenance, and life cycle costs, which are of great significance for the further expansion of renewable energy sources (RESs).

The most significant characteristics of $\mathrm{SiC}$ is the very high electric breakdown field, allowing thinner and shorter drift layers structures, resulting in very low specific on-state resistance even at higher blocking voltages, as can be observed below for different switch technologies (Figure 4).

The conduction as well as switching losses can be significantly reduced, given the much superior dynamic behavior of $\mathrm{SiC}$ devices due to the higher saturated electron drift velocity. Such significant reduction of the overall losses can be translated into additional revenues; for example, increasing the efficiency of a grid-connected PV 
system in Germany by $1 \%$ will return $84 €$ per installed $\mathrm{kW}_{\text {peak }}$, considering a lifetime of 20 years. This in turn justifies the use of more expensive devices. Levels of efficiency as high as 99\% were already demonstrated in several experimental investigations, though going beyond this level is nevertheless not cost effective so that other features shall also be considered [5], [6] (Figure 5).

The first possibility to be considered is using the high-speed switching capability of $\mathrm{SiC}$ devices to increase the switching frequency without much prejudice to the overall losses, allowing a significant reduction of weight and cost of filter inductors. Such characteristic can be observed in Figure 6, where the total losses of a 1,200-V 25-A SiC D-MOSFET and a trench insulated-gate bipolar transistor (IGBT) are compared for a certain current and switching frequency range. A waveform considered here represents the average behavior of a grid-tied inverter with unipolar PWM.

The possibility of operating with reduced losses even at high blocking voltages will allow the use of simplified circuits with fewer semiconductors and power stages. Special characteristics of the switch, for example, normally on behavior depicted by junction fieldeffect transistors (JFETs), shall also be considered when choosing the optimum circuit for a given application [6].

The referred reduced amount of losses along with higher thermal conductivity and the possibility of operating at very high junction temperatures (inherent to $\mathrm{SiC}$ devices only) may also allow a considerable diminution of the heat-sink size and cooling effort, again reducing the weight and cost of the converter.

\section{Transformerless}

\section{Inverter Topologies}

A high-frequency transformer is the key device in classical grid-connected PV power processing systems [7]. It limits the ground current flowing into the grid and ensures that no direct current, which could saturate the distribution transformer, is injected

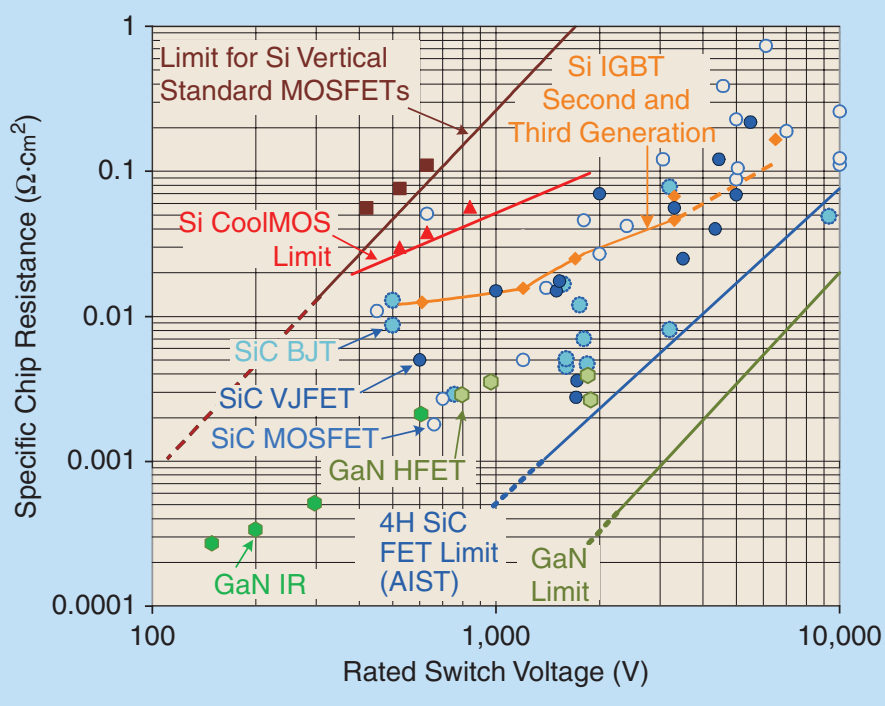

FIGURE 4-Specific chip resistance for different materials and switch technologies [5]. into the grid. Only two parameters have to be considered when selecting the switching converter and its modulation technique: efficiency and line current total harmonic distorsion (THD). However, using a transformer increases the weight, size, and cost of the PV system, which in turn reduces

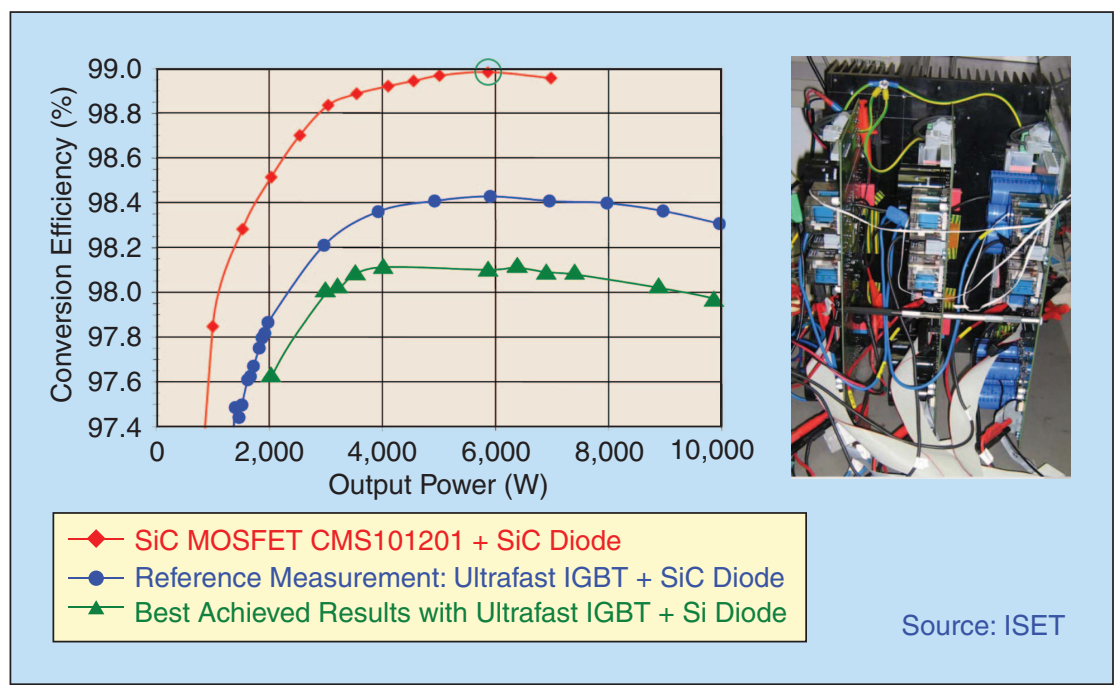

FIGURE 5-Measured efficiency curve of a three-phase inverter employing SiC MOSFETs.

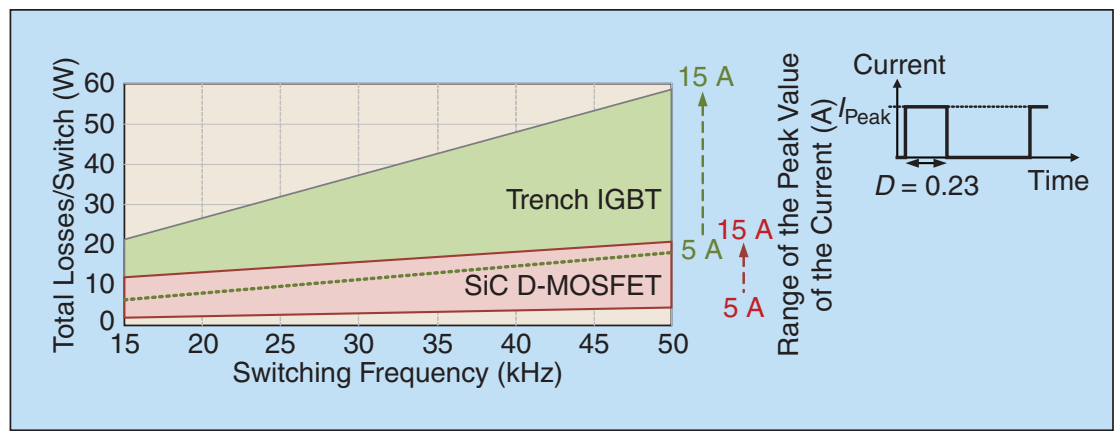

FIGURE 6-Total losses per switch for a given switching frequency and current range [5]. 
its efficiency. These drawbacks have motivated researchers to work on transformerless solutions.

When the transformer is removed from the system, the common-mode behavior has to be carefully considered. The current injected into the ground is only limited by the converter common-mode impedances [mainly due to the electromagnetic compatibility (EMC) filter] and the stray capacitance between the PV generator and ground. This capacitance is high enough to generate strong leakage currents if the inverter impresses a varying voltage across the PV stray capacitance [8]. As a consequence, in PV transformerless systems, the switching converter has to be designed not only for high efficiency and low THD but also to guarantee low ground current injection [9]. Several topologies, apparently based on very different approaches, have been proposed for single-phase transformerless topologies [10]-[12]. Taking into account the general common mode model derived in [8], all the topologies can be systematically analyzed. As a consequence, it is possible to obtain a comprehensive picture of all the different concepts used in those topologies. Additionally, the analysis procedure proposed becomes an useful tool to analyze or derive other solutions.

As a preliminary step, the most significant quality parameters to be evaluated have been described. From the energy generation point of view, the main concern is about efficiency.

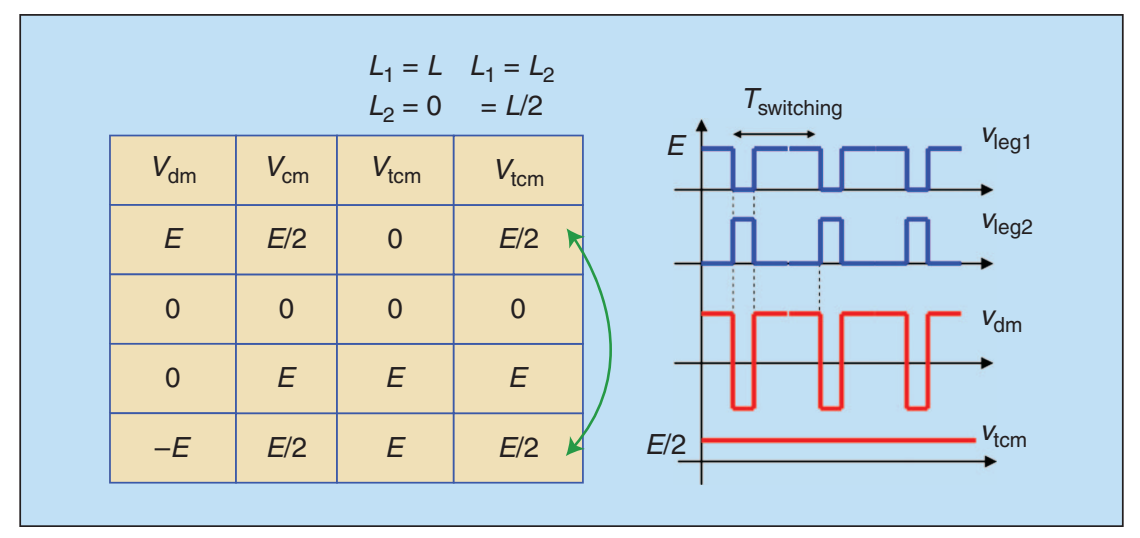

FIGURE 8- Full-bridge analysis for transformerless PV applications.
The main sources of power losses are the converter switching and conduction losses and the energy losses in the output filter. As the operation point of a PV system changes continuously, the efficiency should be obtained considering several operation points. In Europe, the Euro-efficiency coefficient is commonly used for this purpose. From the utility point of view, the main concern is about the line current harmonics, including the dc component, and the current injection into the ground. The line current THD is a function of the inverter output voltage THD. The dc current injection into the grid can be either topologically avoided or controlled by means of a current control loop. Finally, the common-mode current flowing through the ground is a function of the voltage impressed across the stray capacitance of the PV generator to ground. To easily calculate this voltage from any converter topology is very useful to develop a general model of a single-phase PV system for the common mode. This model can be derived considering the switching converter as a twophase voltage source, with reference

to the negative rail of the $\mathrm{dc}$ bus, and including the PV to ground $\left(C_{\mathrm{PVg}}\right)$ and the switches to ground capacitances. The model also has to include the phase and neutral inductors, $L_{1}$ and $L_{2}$, and the common-mode filter impedances $L_{\mathrm{cm}}-C_{\mathrm{cm}}$. The output voltage sources can be expressed in terms of the usual common-mode and differential- 
in all of them is to avoid the connection between the output and the dc bus terminals when the output is short-circuited. Depending on where the additional switches are placed, they could be classified as ac- or dcbypass inverters. Figure 9 shows two examples. With the help of a table similar to the one depicted in Figure 8 , it is possible to systematically derive and justify the modulation technique used in these converters.

A different alternative can be found in the half-bridge topology with no neutral inductance. It provides constant $v_{\text {tcm }}$ at the same time that topologically guarantees the noninjection of dc current into the grid. Nevertheless, it generates only two output voltage levels and requires higher dc bus voltage. Multilevel half-bridge converters have been suggested to improve the output voltage THD. On the other hand, only those solutions that do not introduce any additional connection to the capacitor leg would topologically guarantee that no direct current is injected into the grid.

\section{Multilevel Converters}

Multilevel PWM converters are gaining popularity in the field of renewable energies because of the need of connecting several distributed power sources, whose power is continuously growing, guaranteeing at the same time good power-quality levels [13][20]. They can be used as rectifiers in the case of wind and hydroenergy, where the electricity is generated by ac generators and inverters in the case of wind, solar, hydro, and fuel cell (FC) generation.

There are three basic multilevel topologies: neutral point clamped (NPC), flying capacitor, and cascaded H-bridge (CHB) converters. In the first two topologies, the connected sources cannot be independent; in the case of $\mathrm{CHB}$, the sources can be independent. For this reason, the latter appears very suitable in applications where multiple dc generators are available, typically, solar and FC generation systems. In fact, separate dc sources can be obtained arranging the available sources in distinct groups.

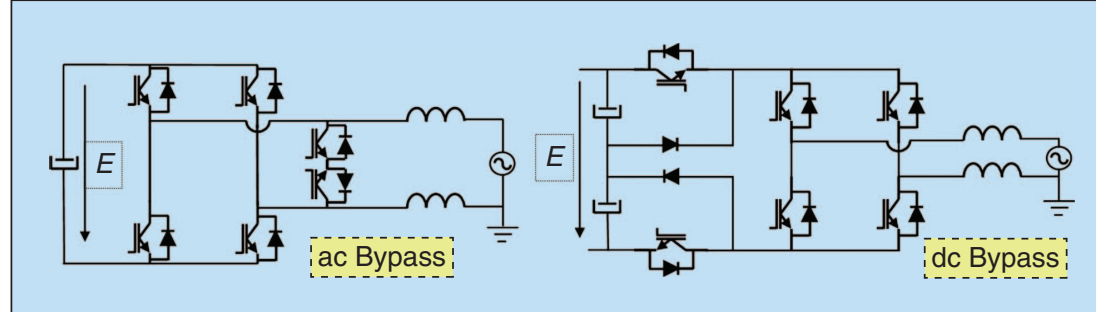

FIGURE 9-The ac-bypass (highly efficient and reliable inverter concept) and dc-bypass converters.

Multilevel active rectifiers improve the absorbed ac currents, thus reducing generator stress; at the same time, they allow precise output voltage regulation, thus eliminating the need for a $\mathrm{dc} / \mathrm{dc}$ converter. Furthermore, in the case of multimegawatt systems with high-voltage generators, they overcome the problem of the high input voltage applied to the converter. In case of dc generation, such as in PV or FC systems, they may overcome the need of a $\mathrm{dc} / \mathrm{dc}$ converter, often in charge of MPPT and voltage boost. Figure 10

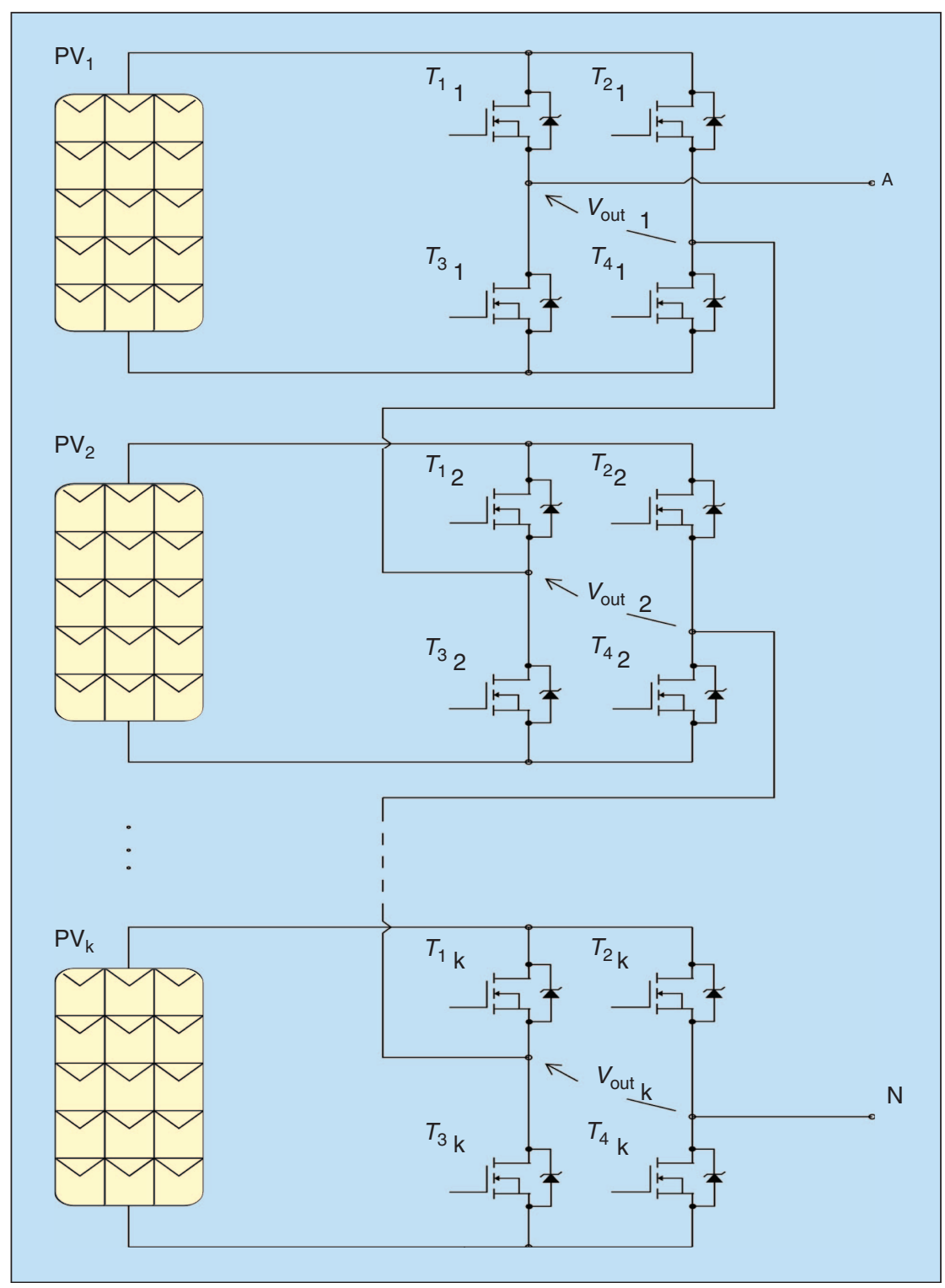

FIGURE 10-A PV system with multilevel inverter. 
shows a schematic diagram of an n-level inverter for solar systems.

The main drawbacks of multilevel converters are the higher number of power devices introducing potential power losses problems and the complexity of the pulse generation that requires the design of ad hoc pattern generators. Current electronic technology overcomes both of them: in fact, power devices (MOSFETs and IGBTs) operating at low-voltage levels have better characteristics than those operating at low voltage, thus reducing or eliminating this gap; moreover, the availability of field-programmable gate arrays (FPGAs) solves the second problem, allowing the implementation on a single chip of both control and modulation algorithm at moderate cost.

\section{Wave Dragon MW Offshore Wave Energy Converter}

Oceans cover approximately 75\% of our planet's surface, and renewable energy comes from the planet in different forms: waves, currents, thermal gradients, salinity gradients, and tides [21]. Until now, more than 1,000 patents have been dedicated to wave energy converters aimed at exploiting this energy. Wave Dragon (Figure 11) is an overtopping device consisting of two wave reflectors, a main platform-body, hydroturbines (lowhead type), electrical generators, and finally, power electronic converters (ac-dc-ac). The Wave Dragon offshore wave energy converter is a slack-moored, floating overtopping device [22]. The design of such a system has attracted many researchers who are active in different research fields to solve problems related to body and wave reflectors construction, hydroturbines, power electronics, electrical machines, and control.

Erik Friis-Madsen, the inventor of the Wave Dragon wave energy converter, and his team are responsible for the development of the body and wave reflectors. He designed the Wave Dragon prototype in the 1:4.5 scale (33-m long and 58-m wide).
This Wave Dragon prototype has operated since 2003 in Nissum Bredning, northwest Denmark. The device is automatically controlled and grid connected as a small power plant. The prototype, shown in Figure 11, is built with steel (total mass including water ballast is equal to 237 tons) [22]. Power produced by RESs should be delivered to the grid. At the point of common coupling, this energy has to meet more and more restrictions defined by the local grid code. Renewable power plants should be robust and efficient. However, at the present stage, this is not an easy task. There are still problems with energy storage, robustness, and power quality that need to be solved. To assure the best immunity and efficiency, the topology presented in Figure 12 is considered optimal. The difficulty of handling large components offshore dictates a limited turbine size and high number of individual turbines. Dedicated to each turbine, full-scale ac-dc-ac converters assure very

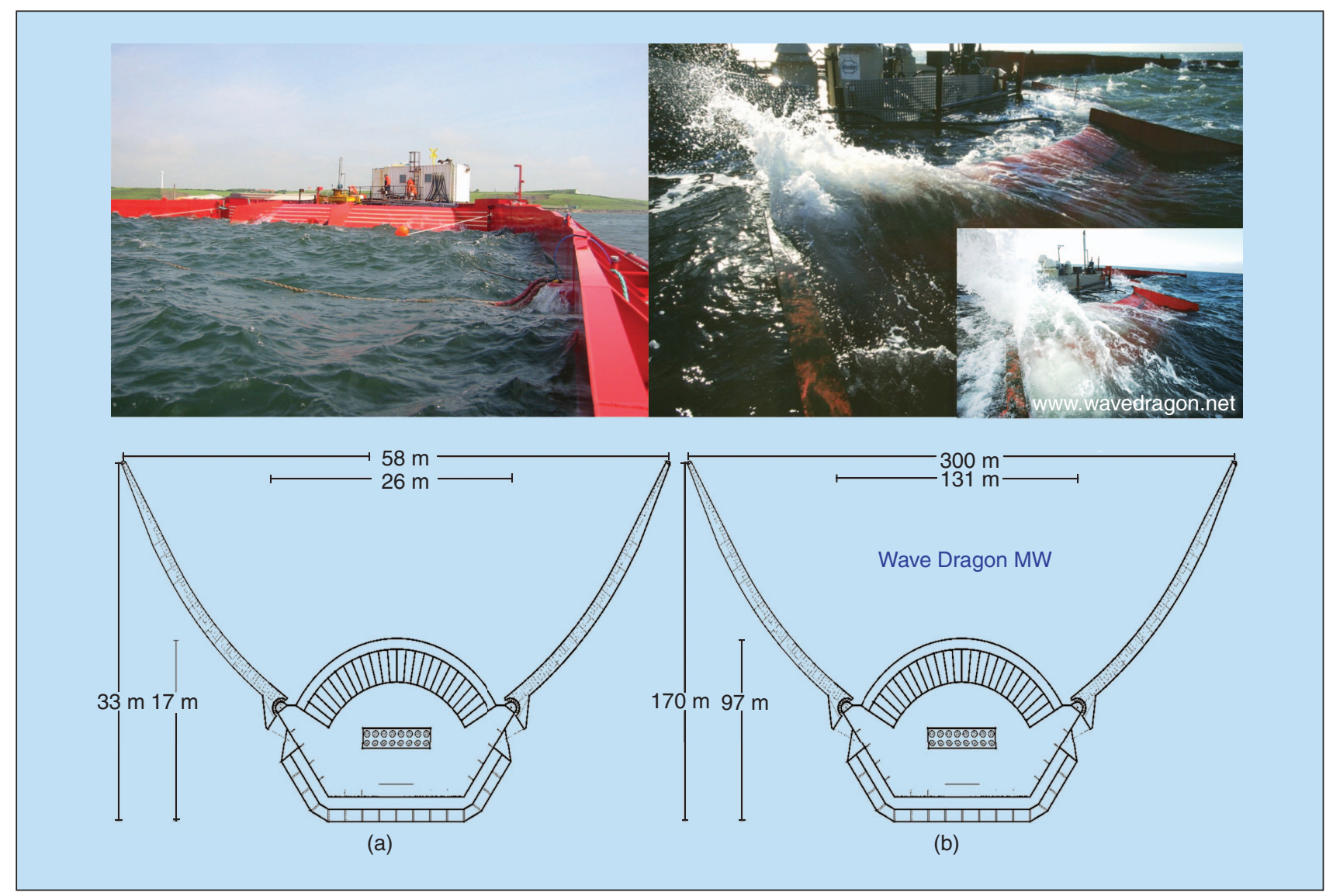

FIGURE 11 -Wave Dragon: (a) small-scale demonstrator; (b) MW full-scale demonstrator (www.wavedragon.net). 


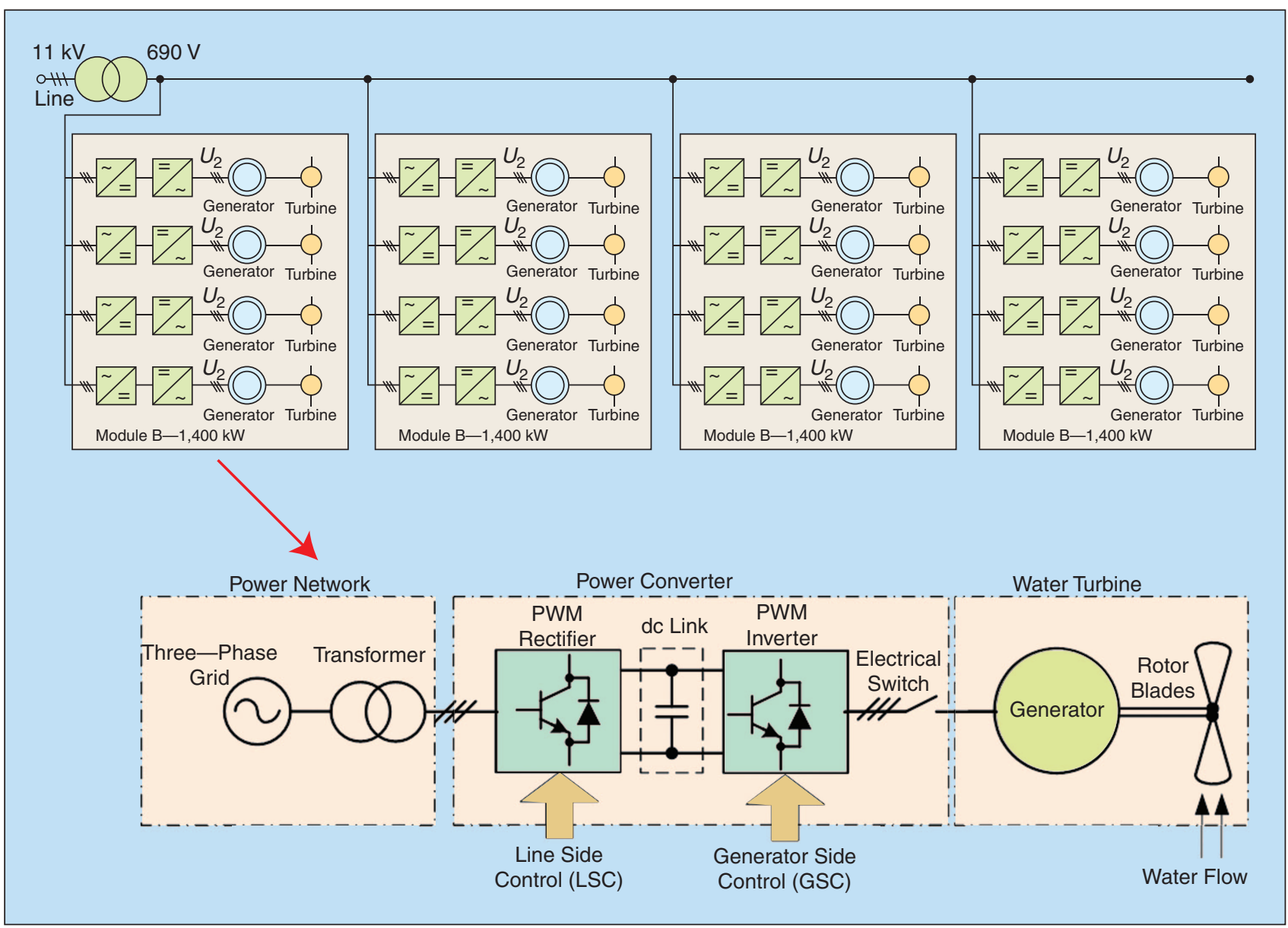

FIGURE 12 - The ac-dc-ac converters as a power electronics interface for wave energy converter.

flexible power conditioning and turbine/generator set speed control. The structure of the proposed ac-dcac consists of two similar ac-dc and dc-ac converters (back-to-back converter). Therefore, it is a well-known, proven technology implemented in many applications (e.g., variable speed drives), which results in favorable costs and the possibility for a relatively easy update. Based on the experience with the scaled prototype shown in Figure 11(a), it is obvious that control of the ac-dc-ac/generators set should be optimized. Control methods for both converters [line side converter (LSC) and machine side converter (MSC)] should be closed-loop-based. Therefore, vector control methods are the only alternative. Chosen control methods can be classical voltage and flux-oriented control (or direct power and torque control) for the LSC and MSC converters under the condition that control methods take into account and solve the following problems (see
Figure 13): harmonics and voltage dips compensation, islanding mode detection and operation, turbine model, and operation point optimization.

On the machine side, there is the possibility to use a low-speed squirrel cage induction machine (SCIM) or a low-speed permanent magnet

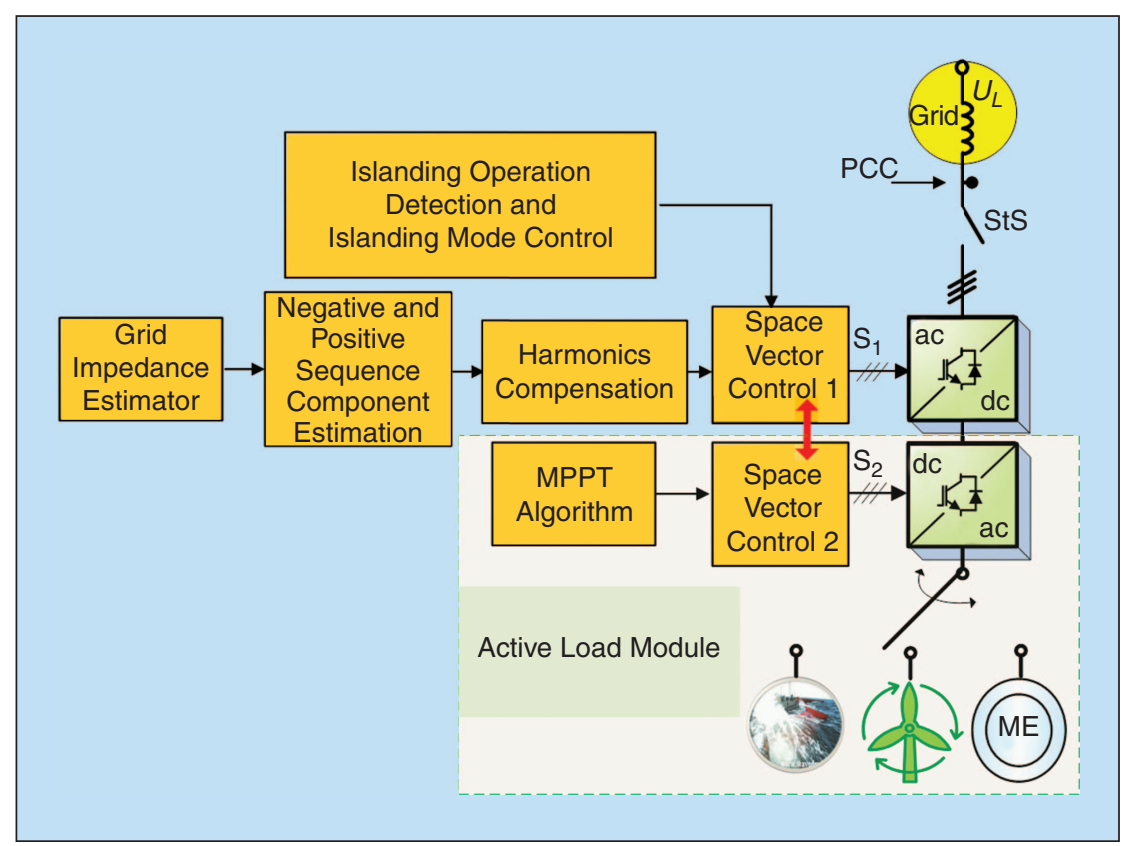

FIGURE 13 - Control accuracy impact on power quality produced by renewable energy. 
synchronous machine (PMSM). In the latter case, the MSC can be constructed as a three-phase diode bridge with step-up chopper. This solution has some advantages; however, control quality is less. A comparison of the different machine types is shown in Table 1.

At the present stage, it can be concluded that a direct-driven SCIM with dedicated ac-dc-ac converter is the best solution. However, it would be advantageous to include one or two permanent magnet generators, as this type of machine does not need external excitation. This would facilitate a black start in case of grid loss, which is a desirable feature in an offshore application. This is because in offshore application a transformer between the grid and RESs should be designed as a set of smaller transformers connected in parallel.

The task is rather demanding, because the full-scale Wave Dragon energy converter will be 170-m long and 300-m wide (total design weight is 33,000 tons) [23]. Wave Dragon will collect overtopped water in a reservoir. Low-head Kaplan hydroturbines in the bottom will be the first link in the energy conversion chain. These turbines are developed by a team at Technische Universität München (TUM), which is lead by Wilfried Knapp, who is also the team leader of the Power Take Off (PTO) group in the project [21]. The turbines convert the hydraulic head in the reservoir into mechanical power. This power (mechanical torque and angular speed) is delivered to the shaft of the electrical machine. At this point, electrical power appears. The electrical machine operates as a generator. However, the produced electrical energy fluctuates as the wave energy fluctuates. In this stage, some effort for energy tuning is needed. This role is given to the ac-dc-ac power electronics converters; these devices convert wild electrical energy to controlled and standardized energy. International teams from the United Kingdom (Petar Igic and Zhongfu Zhou with team) and Poland (Marian
P. Kazmierkowski, Mariusz Malinowski, and Marek Jasinski along with their team) are working in this field.

This activity has been partially supported by the European Union in the framework of the European Social Fund through the Warsaw University of Technology Development Programme. Authors gratefully acknowledge the partial financial support of the European Union Sixth Framework Programme (contract no. 019983 Wave Dragon MW).

\section{The Grid Converter As a Universal Interface for Integrating Renewable Energy in the New Power System}

Smart grids represent the most useful and efficient way of integrating renewable energy generation in the main grid. Power converters are the technology that enables efficient and flexible interconnection of different players (producers, energy storage, flexible transmission, and loads) to the electric power system (Figure 14).

\begin{tabular}{|c|c|c|c|c|}
\hline \multirow[t]{2}{*}{ LP } & FEATURE & PMSM & $\begin{array}{l}\text { SCIM/ } \\
\text { GEARBOX }\end{array}$ & $\begin{array}{l}\text { SCIM DIRECT } \\
\text { DRIVEN }\end{array}$ \\
\hline & \multicolumn{4}{|l|}{ Costs } \\
\hline 1 & Investment & -1 & 1 & 1 \\
\hline \multirow[t]{2}{*}{2} & O\&M & nd & nd & nd \\
\hline & \multicolumn{4}{|l|}{ Performances } \\
\hline 3 & Efficiency & 1 & -1 & 1 \\
\hline \multirow[t]{2}{*}{4} & Lifetime & 1 & -1 & 1 \\
\hline & \multicolumn{4}{|l|}{ Technical risk } \\
\hline 5 & Direct drive (no gearbox) & 1 & -1 & 1 \\
\hline 6 & No overvoltage with runway speed & -1 & 1 & 1 \\
\hline 7 & Do not need magnetizing current & 1 & -1 & -1 \\
\hline 8 & Lower height of system $\mathrm{T} / \mathrm{G} / \mathrm{G}$ & 1 & -1 & 1 \\
\hline \multirow[t]{2}{*}{9} & Lower total weight & -1 & 1 & -1 \\
\hline & \multicolumn{4}{|l|}{ Environmental considerations } \\
\hline 10 & Oil or other critical liquids & 1 & -1 & 1 \\
\hline 11 & Noise & 1 & -1 & 1 \\
\hline 12 & Complete offer from one manufacturer (whole PTO system) & 0 & 0 & 1 \\
\hline 13 & Ability to control more than one generator by one ac/dc converter & -1 & 1 & 1 \\
\hline \multirow[t]{2}{*}{14} & Additional protection requirements & -1 & 0 & 1 \\
\hline & Summary: & 2 & -3 & 9 \\
\hline
\end{tabular}

-1: not good; 0: neutral; 1: good; nd: no data. 
Power electronics is needed not only to connect RESs, distributed power generation system (DPGS), and storage systems to the power system but also for loads, with regulation capability, and transmissions systems [highvoltage dc transmission (HVDC) and flexible ac transmission (HVAC)].

In fact, power consumers may accept regulating the consumed power to contribute to the stability of the grid or to provide an indirect storage [e.g., charging systems for the batteries of hybrid electric vehicles (HEVs)]. Consumers may adapt their power even to accept operation in stand-alone mode when it is not possible to operate a controlled island, and emergency (e.g., in case of hospital) requires an uninterruptible power system (UPS) functionality.

Finally, since it is possible to foresee the operation of different grids at different power levels and based on different technologies such as dc or ac, single-phase or multiphase, the interconnection of these systems through flexible transmission systems such as HVDC and FACTS will allow the transfer of more power, preserving dynamic stability and with minor right of way (ROW) restriction with respect to traditional transmission systems. The possibility of these transmission systems to manage a bidirectional and controlled power flow and full control of reactive power relies on the use of bidirectional energy conversion structures adopting PWM technology and a proper control [24].

Hence, it is possible to foresee that how the synchronous machine that had a central role in the centralized power system (the grid converter also denoted as synchronous converter) will be a major player in the future power system based on smartgrid technologies. While the electromagnetic field has a major role in the synchronous machine, the grid converter is mainly based on semiconductor technology and signal processing, but its connection filter, where the inductor is dominant, still has a crucial role in shaping its frequency behavior. The PWM grid converter is equivalent

\section{An in-depth analysis of the disturbances appearing in grid-connected systems helps in improving the MPPT efficiency.}

to multiple synchronous machines; in fact, the grid converter can control the active and reactive power flow in a wide frequency range [25].

Particularly, if attention is paid to the power converter, the increase in power leads to the use of more voltage levels, leading to more complex structures based on single-cell converter (like NPC multilevel converters) or multicell converter (like CHB or interleaved converters) [26]. In the design and control of the grid converter, the challenges and opportunities are not only related to the need of using lower switching frequency to manage higher power level but also to the availability of more powerful computational device and more distributed intelligence (e.g., in the sensors and PWM drivers) [14], [27]. Some possible solutions to these challenges are in the use of nonlinear analysis and optimization with deterministic and stochastic techniques [28]. These can be applied both at device level to optimize the synchronization with the grid, the harmonic control and stability, and at the system level to detect and manage islanding conditions for low-power DPGS (Figure 15), ridethrough grid faults for highpower DPGS (Figure 16), which in turn contribute to the grid stability and power quality [29]-[32].

\section{FC Systems}

Among the five existing FC technologies, each type can be configured in a system focusing on the market segments that match its characteristics most favorably. Because of their quick start-up potential, low-temperature FCs [alkaline FCs and polymer electrolyte FCs (PEFCs)] are being considered

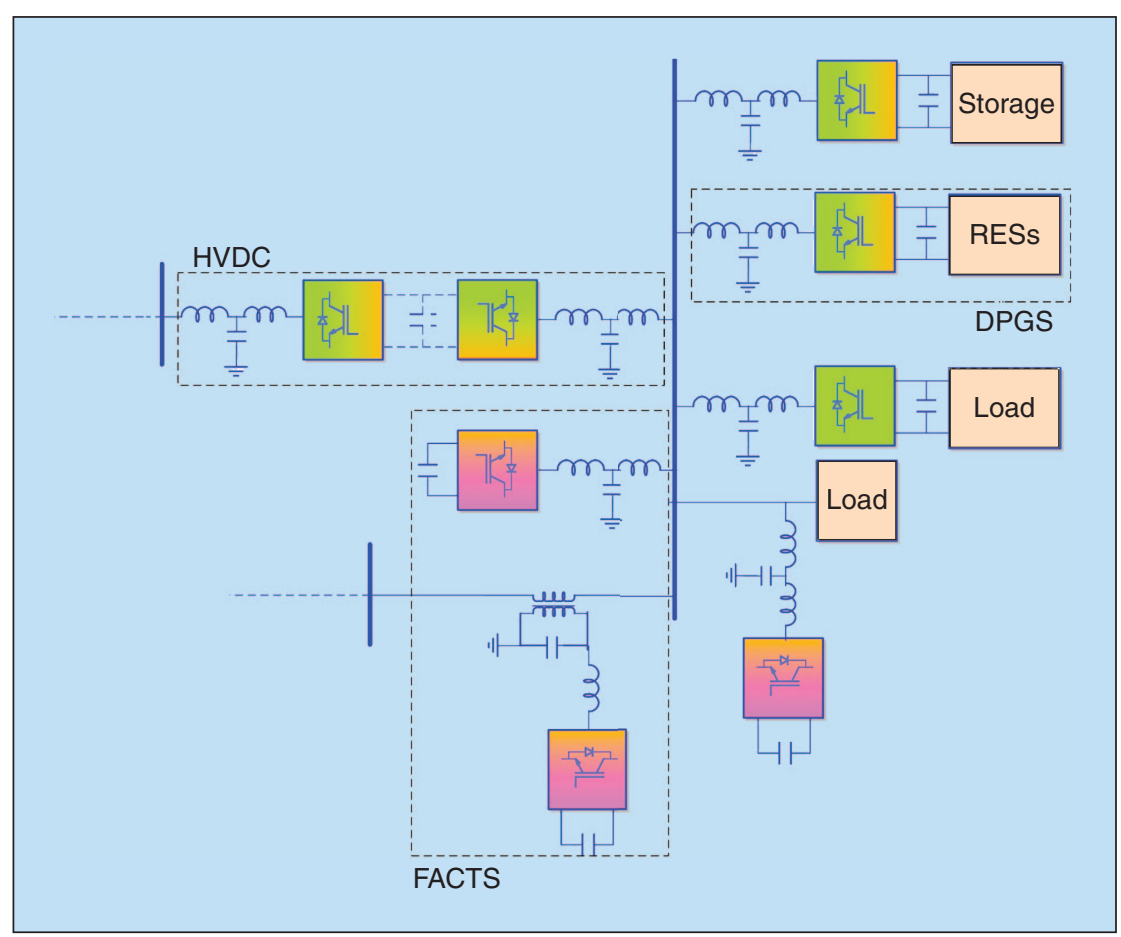

FIGURE 14-Different roles of the grid converter used to interface: RESs, loads, storage systems, flexible ac transmission system devices (FACTS), high-voltage dc transmission (HVDC), and active filters. The green color denotes the exchange of active power, orange the exchange of reactive power, and violet the exchange of harmonics. 


\section{A great number of technological challenges has to be solved before efficient, competitive, reliable FC power generators can be actually} seen on the market.

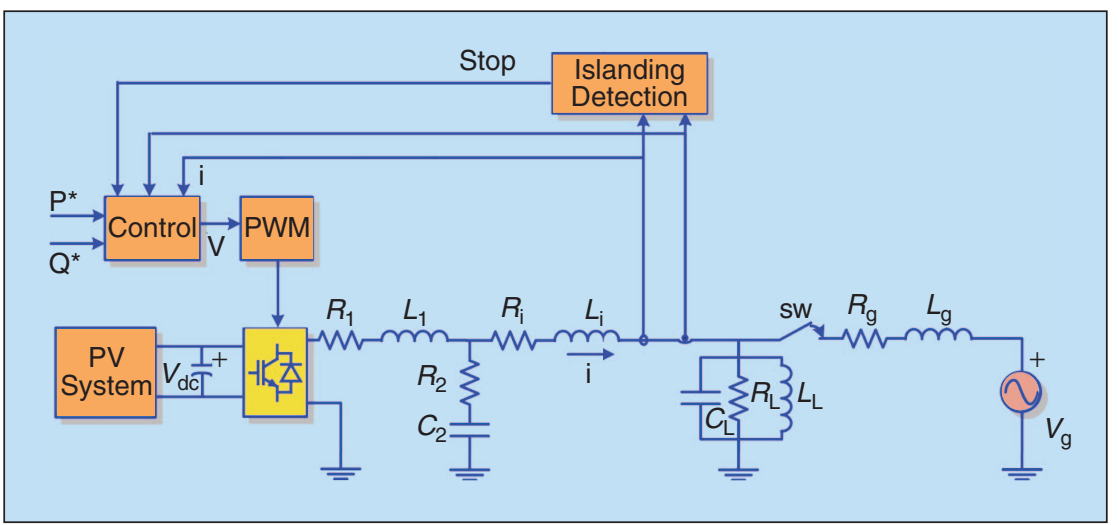

FIGURE 15-Low-power DPGS antiislanding protection.

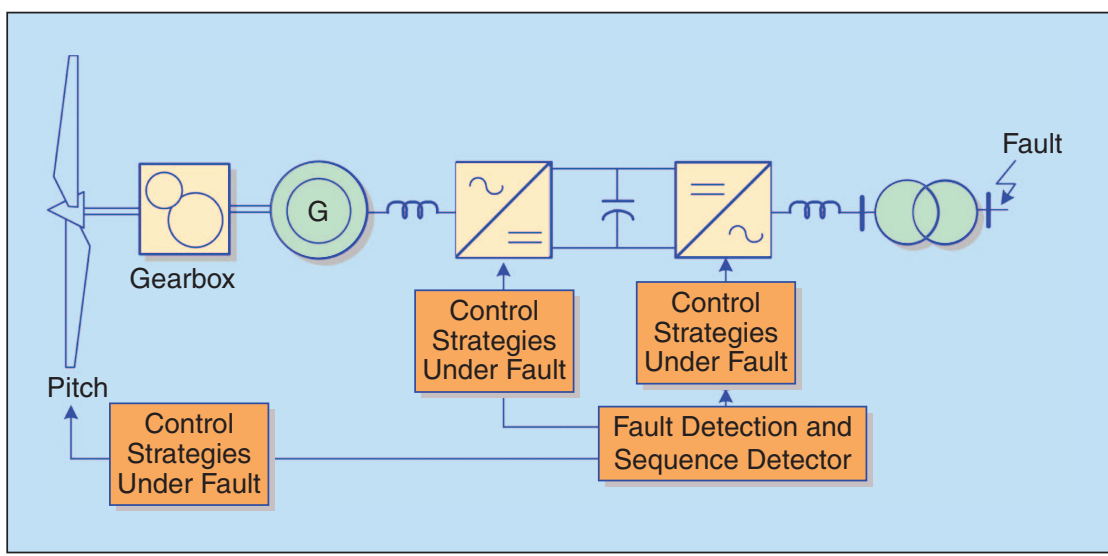

FIGURE 16-High-power DPGS grid fault ride through.

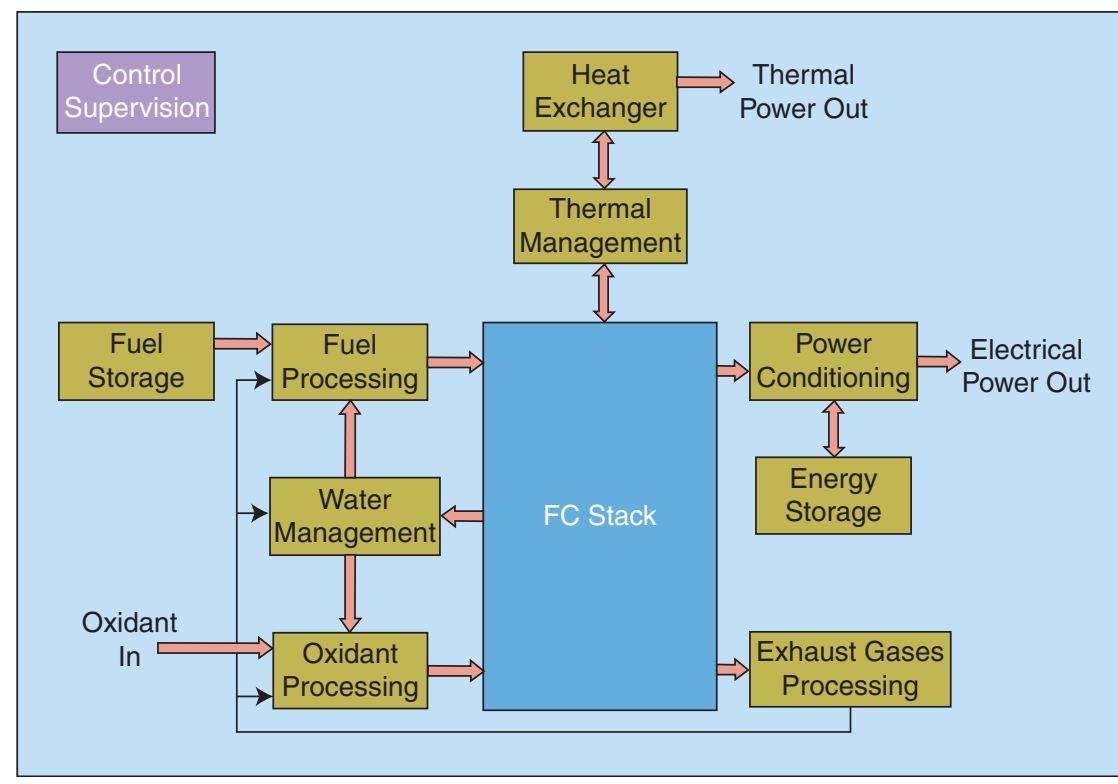

FIGURE 17-An FC system scheme. for portable, residential power and transportation applications. Higher temperature FCs [phosphoric acid FCs, molten carbonate FCs, and solid oxide FCs (SOFCs)] are often considered for stationary power generation. Nevertheless, because of their solid electrolyte, SOFCs are also considered for transportation applications by some car manufacturers or car suppliers.

If FC stacks are intrinsically able to respond quickly to the load changes, their balance of plant subsystems (hydrogen supply, air compressor, gas humidification, and coolant circuit) respond in times that are several orders of magnitude higher. This apparent contradiction diminishes the reliability and performance of the whole FC system. Figure 17 presents a general scheme of an FC system. As it can be seen, an FC stack needs a lot of ancillaries to operate. The fuel must first be produced or stored. Then, it is finally processed (mostly, in terms of pressure, hydration, and flow regulation) before entering the FC stack. The oxidant must also be processed in the same way. For both fuel and oxidant gases, the water produced by the FC stack can be removed from the exhaust gases to be reused in the hydration of incoming gases. Then, as the electrochemical reaction is exothermal and as the FC stack must be operated in a dedicated temperature range, thermal management is essential. Moreover, the gas supplying and the stack thermal management are strongly coupled with the gas hydration level control. Finally, electrical power conditioning (in association or not with an energy-storage device) and overall control of the whole system are other important subsystems [33].

Of course, considering the whole FC system, the gains in terms of both energy savings and pollutant emissions depend greatly on whether this whole FC system is well designed or not and on whether global optimization has been performed on this system or not. Accordingly, a great number of technological challenges has to be solved before efficient, competitive, reliable FC power generators can be actually seen on the market. Among them, electrical 
engineering relating technological challenges are of greatest importance.

- Modeling challenges have to be overcome. The difficulty is here to propose an efficient, easy-to-tune, real-time suitable model of the whole FC system. Many solutions have already been proposed: analytical models, gray and black-box models [34].

- New power conversion solutions have to be proposed for those high-current, low-voltage power devices. The coupling (and the relating optimization) of the $\mathrm{FC}$ stack with electrical energy-storage devices (e.g., supercapacitors and batteries of flywheels) has to be investigated to propose new high-efficient hybridized power architectures.

The durability must be increased, and new online diagnostic tools can be proposed (Figure 18), based directly on the power converter [35]. Those tools are used to modify (in real time) the control laws on an FC system to improve the lifetime of an FC stack.

\section{Conclusions}

In this article, a short summary of some speeches given during SERENE has been given. The contributions have been mainly focused on power electronics for PV and sea wave energies, pointing out some aspects related to efficiency, reliability, and grid integration. Finally, main issues concerning FC systems as generators based on hydrogen as a low environmental impact energy vector have been discussed.

\section{Biographies}

Giovanni Spagnuolo (gspagnuolo@ unisa.it) received the degree in electronic engineering from the University of Salerno, Italy, in 1993 and the Ph.D. degree in electrical engineering from the University of Napoli Federico II, Italy, in 1997. He joined the Dipartimento di Ingegneria dell'Informazione ed Ingegneria Elettrica of the University of Salerno, Italy, where he worked as a postdoctoral fellow from 1998 to 1999, an assistant

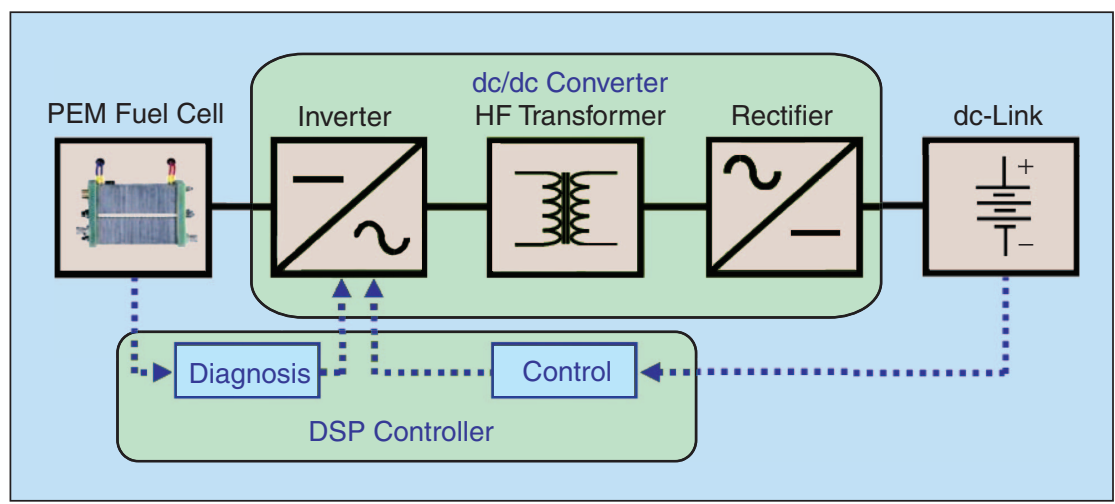

FIGURE 18-Online diagnosis of the FC stack based on the electrical power converter.

professor of electrical sciences from 1999 to 2003, and as an associate professor since 2004. He is an associate editor of IEEE Transactions on Industrial Electronics and a Member of the IEEE. His research interests are in the analysis and simulation of switching converters, circuit and systems for RESs, and tolerance analysis and design of electronic circuits.

Giovanni Petrone received the laurea degree in electronic engineering from the University of Salerno, Italy, in 2001 and the Ph.D. degree in electrical engineering from the University of Napoli Federico II, Italy, in 2004. Since 2005, he has been an assistant professor of electrotechnics at the University of Salerno. His research interests are in the analysis and design of switching converters for telecommunication applications, RESs in distributed power systems, and tolerance analysis of electronic circuits.

Samuel Vasconcelos Araújo received the bachelor's degree in electrical engineering in 2006 at the Federal University of Ceará, Brazil, and the master of science degree in renewable energy and energy efficiency at the University of Kassel, Germany, in 2007. In the same year, he joined the Institute for Solar Energy Technology, Kassel, Germany, and since 2009, he has worked in the Center of Competence for Distributed Electric Power Technology (KDEE). $\mathrm{He}$ is currently pursuing his Ph.D. degree at the University of Kassel. His main fields of interest are the optimization of power circuits and investigation of innovative semiconductor devices.

Carlo Cecati (carlo.cecati@univaq.it) received the Dr.Ing. degree in electrotechnics from the University of L'Aquila, L'Aquila, Italy, in 1983. Since then, he has been with the Department of Electrical and Information Engineering, University of L'Aquila, where he was a professor of industrial electronics and drives and a rector's delegate. $\mathrm{He}$ is a coeditor-in-chief of IEEE Transactions on Industrial Electronics and has been the technical editor of IEEE/ ASME Transactions on Mechatronics. He has been a cochair of many IEEE conferences. From 2000 to 2004, he was an Administrative Committee (AdCom) member of the IES, and from 2005 to 2006, he was an IES vice president. Since 2007, he has been an IES senior AdCom member and IES Region 8 coordinator. He is a Fellow of the IEEE. His research and technical interests cover several aspects of power electronics and electrical drives.

Erik Friis-Madsen received his M.Sc. degree in civil engineering and is the owner of the consultant engineering company Löwenmark FRI. He has 35 years of experience as a consultant engineer and has performed several projects on sophisticated energy systems. He is also the founder and managing director of Wave Dragon ApS, the development company for the Wave Dragon. Furthermore, he has participated in several product development projects 
within the construction industry. He is a council member of the Danish Association of Engineers and a member of the board of the Danish Society of Wave Energy.

Eugenio Gubia received the M.Sc. and Ph.D. degrees in industrial engineering from the Public University of Navarre, Spain, in 1995 and 2003, respectively. He joined the Electrical and Electronic Department of the Public University of Navarre in 1996, where he is currently an associate professor. In 2002, he joined the Electrical Engineering, Power Electronics, and Renewable Energy Research Group. From June to December 2005, he worked as a guest researcher at the Center for Power Electronics Systems (CPES) in the field of electromagnetic compatibility. His research interests are in the field of power electronics, renewable energy systems, onboard systems, high-frequency phenomena in electrical machines, and electromagnetic compatibility.

Daniel Hissel obtained an electrical engineering degree from the Ecole Nationale Supérieure d'Ingénieurs Electriciens de Grenoble in 1994. He received a Ph.D. degree from the Institut National Polytechnique de Toulouse in 1998. From 1999 to 2000, he worked for ALSTOM Transport in Tarbes, France, where he was a system engineer on electrical and FC bus projects. From 2000 to 2006, he was an associate professor at the University of Technology Belfort. From 2006 to 2008, he was a full professor at the University of Franche-Comté and the head of the Fuel Cell Systems Research Team of the Laboratory of Electrical Engineering and Systems. Since 2008, he has been a full professor at the University of Franche-Comté and head of the energy systems modeling research team at the FrancheComte Electronic, Mechanical, Thermal, Optical-Sciences and Technology (French National Centre for Scientific Research) Institute. He is an associate editor of IEEE Transactions on Industrial Electronics and an associate editor of ASME Fuel Cell Science and Technology. He is also the president of the IEEE Vehicular Technology Society French Chapter and a member of the advisory board of the French National Network on Electric Vehicles and HEV. He is a member of the Fuel Cell Laboratory Institute (dedicated to FC research) and has published more than 150 scientific papers in peer-reviewed international journals and international conferences. He is a Senior Member of the IEEE. His research activities are concerning FC systems dedicated to automotive and stationary applications, modeling, nonlinear control, and energy optimization of these systems and FC system diagnosis.

Marek Jasinski received the M.Sc.E.E. degree with distinction in electrical engineering from the Institute of Control and Industrial Electronics, Warsaw University of Technology (WUT), Poland, in 2000. $\mathrm{He}$ is currently with the Institute of Control and Industrial Electronics, WUT. Since 2006, he has worked on the Wave Dragon project in the PTO group (power electronics energy conversion and generator control). In 2009, he worked as a guest researcher of the Vestas Power Program. He is a Member of the IEEE. His research activity deals with the control of ac-dc-ac converters.

Wilfried Knapp graduated with a diploma in mechanical engineering from TUM in 1984. Since 1984, he has worked as a research assistant with the Institute for Hydraulic Machinery and Plants, TUM. He received a Ph.D. degree in 1990 on investigations of performance curve instabilities in centrifugal pumps. He is the head of the laboratory at Lehrstuhl für Fluidmechanik, TUM.

Marco Liserre (liserre@ieee.org) received the M.Sc. and Ph.D. degrees in electrical engineering from the Polytechnic of Bari, Italy, in 1998 and 2002, respectively. Since January 2004, he has been an assistant professor with the Polytechnic of Bari, where he is engaged in teaching courses of power electronics, industrial electronics, and EMs. He has authored or coauthored more than 127 technical papers and has authored three book chapters. He was a visiting professor at Aalborg University, Denmark, Alcala de Henares, Spain, and at Christian-Albrechts University of Kiel, Germany. He has given lectures at different universities and tutorials for the following conferences: IEEE Energy Conversion Congress and Exposition 2009, IEEE Power Electronics Specialists Conference 2008, ISIE 2008, European Conference on Power Electronics and Applications (EPE) 2007, Annual Conference of the IECON 2006, ISIE 2006, and IECON 2005. He was a reviewer for international conferences and journals. Within the IES, he has been responsible for student activities, an AdCom member, an editor of the newsletter, and responsible for Region 8 membership activities. $\mathrm{He}$ is an associate editor of IEEE Transactions on Industrial Electronics. $\mathrm{He}$ is the founder of IEEE Industrial Electronics Magazine, and he was also editor-in-chief from 2007 to 2009. He received the IES 2009 Early Career Award. Currently, he is the IEEE-IES vice president for publications. His research interests include industrial electronics applications to DPGSs based on renewable energies. He is a senior member of the IES, the Power Electronics Society, and the Industry Applications Society.

Pedro Rodriguez received the B.S. degree from the University of Granada, Spain, in 1989, and the M.S. and Ph.D. degrees from the Technical University of Catalonia (UPC), Barcelona, Spain, in 1994 and 2004, respectively, all in electrical engineering. In 1990, he was an assistant professor at UPC, where he became an associate professor in 1993. In 2005, he was a researcher at the CPES, Virginia Polytechnic Institute and State University, Blacksburg. In 2006, he was a researcher in the Institute of Energy Technology, Aalborg University, Denmark. $\mathrm{He}$ is currently the head of the Research Group on Renewable Electrical Energy Systems, Department of Electrical Engineering. He has authored or coauthored more than 100 papers in technical journals and conferences and holds two patents. He 
is a member of PELS, IES, and IAS. $\mathrm{He}$ is also a Member of the IEEE. His research interests include power conditioning, integration of distributed energy systems, and control of power converters.

Remus Teodorescu received the Dipl.Ing. degree in electrical engineering from Polytechnical University of Bucharest, Romania, in 1989 and the Ph.D. degree in power electronics from the University of Galati, Romania, in 1994. In 1998, he joined Aalborg University, where he currently works as a full professor. He published more than 120 papers, one book, and has three patents pending. He was a corecipient of the Technical Committee Prize Paper Award at the 1998 IEEE IAS Annual Meeting and the Third ABB Prize Paper Award at the 2002 IEEE Optim. He is a Senior Member of the IEEE, associate editor for IEEE Power Electronics Letters, and chair of the IEEE Danish joint IES/ PELS/IAS Chapter. He is the founder and coordinator of the Green Power Laboratory at Aalborg. His research interests include design and control of power converters used in renewable energy systems, distributed generation, mainly wind power and PVs, computer simulations, and digital control implementation.

Peter Zacharias received the Dipl.-Ing. and Dr.-Ing. degrees in electrical engineering from Otto-von-Guericke University Magdeburg, Germany, in 1979 and 1981, respectively. He worked at the University of Magdeburg until 1990 as an associate professor for power electronics. From 1990 to 1995, he worked at Lambda Physik GmbH Goettingen and later joined ISET Kassel, Germany. He then joined Eupec GmbH in Warstein, Germany. In 2005, he joined the University of Kassel as a professor for electric power supply systems. He founded the KDEE in 2009.

\section{References}

[1] N. Femia, G. Petrone, G. Spagnuolo, and M. Vitelli, "A technique for improving P\&O MPPT performances of double-stage grid-connected photovoltaic systems," IEEE Trans. Ind. Electron., vol. 56, no. 11, pp. 4473-4482, Nov. 2009.

[2] G. Petrone, G. Spagnuolo, and M. Vitelli, "Analytical model of mismatched photovoltaic fields by means of Lambert W-function," Sol. Energy. Mater. Sol. Cells, vol. 91, no. 18, pp. 1652-1657, Nov. 2007.

[3] N. Femia, G. Petrone, G. Spagnuolo, and M. Vitelli, "Optimization of perturb and observe maximum power point tracking method," IEEE Trans. Power. Electron., vol. 20, no. 4, pp. 963-973, July 2005.

[4] N. Femia, G. Lisi, G. Petrone, G. Spagnuolo, and M. Vitelli, "Distributed maximum power point tracking of photovoltaic arrays: Novel approach and system analysis," IEEE Trans. Ind. Electron., vol. 55, no. 7, pp. 2610-2621, July 2008.

[5] B. Sahan, S. V. Araújo, T. Kirstein, L. Menezes, and P. Zacharias, "Photovoltaic converter topologies suitable for SiC-JFETs," in Proc. European Conf. Power Conversion and Intelligent Motion (PCIM), May 2009.

[6] S. V. Araújo and P. Zacharias, "Analysis on the potential of silicon carbide MOSFETs and other innovative semiconductor technologies in the photovoltaic branch," in Proc. 13th European Conf. Power Electronics and Applications (EPE), Sept. 2009.

[7] M. Cacciato, A. Consoli, R. Attanasio, and F. Gennaro, "Soft-switching converter with HF transformer for grid-connected photovoltaic systems," IEEE Trans. Ind. Electron., to be published.

[8] E. Gubia, P. Sanchis, A. Ursúa, J. Lopez, and L. Marroyo, "Ground currents in single-phase transformerless photovoltaic systems," Prog. Photovoltaics: Res. Appl., vol. 15, no. 7, pp. 629-650, Nov. 2007.

[9] C. Cavalcanti, C. Oliveira, M. Farias, A. S. Neves, M. S. Azevedo, and C. Camboim "Modulation techniques to eliminate leakage currents in transformerless threephase photovoltaic systems," IEEE Trans. Ind. Electron., to be published.

[10] S. B. Kjaer, J. K. Pedersen, and F. Blaabjerg, "A review of single-phase grid-connected inverters in photovoltaic modules," IEEE Trans. Ind. Applicat., vol. 41, no. 5, pp. 1292 1306, 2005.

[11] R. González, E. Gubía, J. López, and L. Marroyo, "Transformerless single-phase multilevel-based photovoltaic inverter," IEEE Trans. Ind. Electron., vol. 55, no. 7, pp. 2694 2702, July 2008.

[12] S. Araujo, P. Zacharias, and R. Mallwitz, "Highly efficient single-phase transformerless inverters for grid-connected photovoltaic systems," IEEE Trans. Ind. Electron., to be published.

[13] J. R. Rodriguez and J.-S. Peng, "Multilevel inverters: A survey of topologies, control, and applications," IEEE Trans. Ind. Electron., vol. 49, no. 4, pp. 724-738, 2002.

[14] L. G. Franquelo, J. Rodriguez, J. I. Leon, S. Kouko, R. Portillo, and M. A. M. Prats, "The age of multilevel converters arrives," IEEE Ind. Electron. Mag., vol. 2, no. 2, pp. 28-39, June 2008.

[15] H. Ertl, J. W. Kolar, and F. C. Zach, "A novel multicell DC-AC converter for applications in renewable energy systems," IEEE Trans. Ind. Electron., vol. 49, no. 5, pp. 1048-1057, 2002.

[16] S. Alepuz, S. Busquets-Monge, J. Bordonau, J. Gago, D. Gonzalez, and J. Balcells, "Interfacing renewable energy sources to the utility grid using a three-level inverter,' IEEE Trans. Ind. Electron., vol. 53, no. 5, pp. 1504-1511, 2006.

[17] E. Villanueva, P. Correa, J. Rodriguez, and M. Pacas, "Control of a single-phase cascaded H-bridge multilevel inverter for grid-connected photovoltaic systems," IEEE Trans. Ind. Electron., vol. 56, no. 11, pp. 4399-4406, 2009.

[18] E. Ozdemir, S. Ozdemir, and L. M. Tolbert, "Fundamental-frequency-modulated sixlevel diode-clamped multilevel inverter for three-phase stand-alone photovoltaic system," IEEE Trans. Ind. Electron., vol. 56 no. 11, pp. 4407-4415, 2009.

[19] G. Grandi, C. Rossi, D. Ostojic, and D. Casadei, "A new multilevel conversion structure for grid-connected PV applications," IEEE Trans. Ind. Electron., vol. 56, no. 11, pp. 4416-4424, 2009.

[20] C. Cecati, F. Ciancetta, and P. Siano, "A multilevel inverter for photovoltaic systems with fuzzy logic control," IEEE Trans. Ind. Electron., vol. 57, 2010, submitted for publication.

[21] Renewable Energy Technologies. Ocean energy conversion in Europe. Published in the framework of the Co-ordinated Action on Ocean Energy. EU project under FP6 Priority: 6.1.3.2.3 [Online]. Available: http:// www.ca-oe.org

[22] Available: http://www.wavedragon.net/

[23] L. Christensen, E. Friis-Madsen, J. Peter Kofoed, and J. Tedd, "Worlds largest wave energy project 2007 in Wales," in Proc. PoweGen 2006 Conf.

[24] S. Cole and R. Belmans, "High voltage direct current: From large-scale power transmission to flexible transmission systems," IEEE Ind. Electron. Mag., vol. 3, no. 4, pp. 19-24, Dec. 2009

[25] F. Blaabjerg, R. Teodorescu, M. Liserre, and A. V. Timbus, "Overview of control and grid synchronization for distributed power systems," IEEE Trans Ind. Electron. vol. 53, no. 5, pp. 1398-1409, Oct. 2006.

[26] J. M. Carrasco, L. G. Franquelo, J. T. Bialasiewicz, E. Galván, R. C. P. Guisado, M. M. Prats, J. I. León, and N. Moreno-Alfonso, "Power electronic systems for the grid integration of renewable energy sources: A survey," IEEE Trans. Ind. Electron., vol. 53, no. 4, pp. 1002-1016, Aug. 2006.

[27] J. Wang, A. Huang, W. Sung, Y. Liu, and B. J. Baliga, "Smart grid technologies," IEEE Ind. Electron. Mag., vol. 3, no. 2, pp. 16-23, June 2009.

[28] J.S. Lai, "Power conditioning circuit topologies," IEEE Ind. Electron. Mag., vol. 3, no. 2, pp. 24-34, June 2009.

[29] M. Liserre, A. Dell'aquila, and F. Blaabjerg, "Genetic algorithm-based design of the active damping for an LCL-filter threephase active rectifier," IEEE Trans. Power Electron., vol. 19, no. 1, pp. 76-86, Jan. 2004.

[30] P. Rodriguez, A. Timbus, R. Teodorescu, M. Liserre, and F. Blaabjerg, "Flexible active power control of distributed power generation systems during grid faults," IEEE Trans. Ind. Electron., vol. 54, no. 5, pp. 2583-2592, Oct. 2007.

[31] P. Rodríguez, A. Timbus, R. Teodorescu, M. Liserre, and F. Blaabjerg, "Reactive power control for improving wind turbine systems behaviour under grid faults,' IEEE Trans. Power Electron., vol. 24, no. 7, pp. 1798-1801, July 2009.

[32] R. A. Mastromauro, M. Liserre, T. Kerekes, and A. Dell'aquila, "A single-phase voltage controlled grid connected photovoltaic system with power quality conditioner functionality," IEEE Trans. Ind. Electron., vol. 56, no. 11, pp. 4436-4444, Nov. 2009

[33] M. C. Pera, D. Candusso, D. Hissel, and J. M. Kauffmann, "Power generation by fuel cells," IEEE Ind. Electron. Mag., vol. 1, no. 3, pp. 28-37, Fall 2007.

[34] S. Jemei, D. Hissel, M. C. Péra, and J. M. Kauffmann, "A new modeling approach of embedded fuel cell generators based on artificial neural network," IEEE Trans. Ind. Electron., vol. 55, no. 1, pp. 437-447, 2008.

[35] A. Narjiss, D. Depernet, D. Candusso, F. Gustin, and D. Hissel, "Online diagnosis of PEM fuel cells," in Proc. EPE-PEMFC Conf., Poznan, Poland, 2008, pp. 749-754. 